\title{
Predictors of Performance in Licensure Examination for Teachers
}

\author{
Marie Ann Gladys G. Delos Angeles \\ CIT College Research Office, Cagayan State University Aparri, Cagayan, Philippines \\ Received November 20, 2019; Revised December 24, 2019; Accepted December 30, 2019
}

Copyright $\odot 2020$ by authors, all rights reserved. Authors agree that this article remains permanently open access under the terms of the Creative Commons Attribution License 4.0 International License

\begin{abstract}
The study aimed to identify variables that best predict the performance of the Teacher Education graduates of a university in Cagayan Valley, Philippines. It aimed to assess the quality of the process variables namely: curriculum and instruction. The descriptive correlation research design was employed, and appropriate descriptive statistics were used. Determination of predictors of the teacher licensure performance was done through Regression analysis. Two sets of questionnaires were administered to respondents who were determined using a purposive-snowball sampling technique. The results of the study revealed that variables clustered along the quality of curriculum and qualities of instruction are the variables most significantly related to LET performance. Attainment of course objectives, the relevance of course requirements and mastery of the subject matter were the curriculum variables significantly related to LET performance. On instructional quality, the relevance of written requirements and performance of instructors are highly significant to LET performance. The strongest predictors of LET performance identified in this study are professors' mastery of the subject matter and the quality of the content of the general education courses.
\end{abstract}

Keywords Curriculum, Higher Education, Instructional Quality, Licensure Examination Performance, Predictors

\section{Introduction}

Education is one of the primo dial needs of any individual for him to keep the pace of the requirements of the changing times. It is an agent that moves an individual to develop his craft and attain his potentials as a human being.

Republic Act 9155 defines quality education as the appropriateness, relevance, and excellence of the education given to meet the needs and aspirations of each Filipino citizen and the Philippine society as a whole. As such, the state shall aim to promote and maintain the quality of access to education as well as the benefits of education by all its citizens. Hence, to ensure that quality education is acquired and accessible to every citizen of the country there is a need to ensure that all aspects of the educative process shall include all work towards the attainment of this goal.

One important aspect of the educative process that defines quality education is the quality of its human resource-the teacher. With high-quality teachers, there shall be high-quality basic education, for it is universally recognized that the teacher is the key to the effective delivery of the teaching-learning process. Research [1] shows that students who have access to highly qualified teachers achieve at a high rate, regardless of other factors. The teacher factor also plays a pivoting role in effective learning. Their educational qualifications can indeed affect teaching efficiency.

The challenge then is for the government to produce qualified teachers which can be produced through an authentic educational program and high-quality educational process. Teachers' quality is the keyword for ensuring the quality of education, indicated by the quality of output and outcome. Without qualified, competent teachers, it is impossible to build a high-quality education. On the other hand, a qualified and competent teacher will not be able to carry out their tasks professionally without the proper conditions that support their tasks. Hence, on the one hand, we need to improve teachers' quality continually, and on the other hand, we need to provide a proper condition to support teachers in their professional tasks.

In providing basic education, quality must not be compromised. It is essential that conscious effort is made to ensure quality in order to achieve the goals of basic 
education. Quality basic education will ensure effective learning outcomes and enable beneficiaries to better their living standards as well as contribute more substantially to the socio-economic progress of the country. To ensure that quality education is attained, Higher Education Institutions (HEI's) are mandated to commit and practice the development of an institutional culture that recognizes the importance of quality and the continuous enhancement of quality of services.

In the Philippines, all persons involved in teaching, supervision, and administration of all elementary and secondary schools are required to pass the Licensure Examination for Teachers (LET) [2]. In addition, the Philippines' line agency in charge of the supervision of higher education institutions through its memorandum order (CMO) No. 30 s. 2004 provided rules and guidelines for the implementation of Revised Policies and Standards for the Undergraduate Teacher Education Curriculum [3]. Such CMO contains the response to the challenges of the government for Teacher Education Institutions (TEI) to make the pre-service training of the prospective basic education teachers responsive to the rapid changes in society. One key feature of the new teacher education curriculum is the incorporation of a set of competencies defined in the National Competency-Based Teacher Standards (NCBTS). The NCBTS serves as the mold for both pre-service and in-service education and training. The pre-service teachers shall be formed using this mold while the in-service teachers shall use the same reference to continue and deepen their personal and professional development.

With all these efforts of the government to improve the quality of education in the country, it is a challenge for all the stakeholders namely: CHED, TEI's, PRC, the Department of Education and the Civil Service Commission to form a greater partnership towards the attainment of this goal.

Consistent with the above vision of producing teachers responsive to the needs of the human resources in the country, as well as to provide quality instruction, innovations in the implementation of the Bachelor in Secondary Education (BSEd) and Bachelor in Elementary Education (BEEd) programs must be pursued. The need to determine areas where teacher-education programs could improve the performance of the LET must be sought.

\subsection{Objectives of the Study}

The study aimed to determine the assessment of the teacher education graduates on their curriculum and the quality of instruction provided during their undergraduate courses. The study further determined the variables that best predict the performance in the licensure examination.

\section{Materials and Methods}

\subsection{Research Design}

The descriptive-correlation design was employed, where the analysis of the extent to which the graduates' performance in their academics, the teacher education curriculum and the quality of instruction provided by the institution influenced their performance in the teachers' licensure examination. Shuttleworth [4] affirmed that descriptive design is a scientific method that involves observing and describing the behavior of a subject without influencing it in any way. The subject is being observed in a completely natural and unchanged natural environment. Moreover, descriptive research is often used as a pre-cursor to quantitative research designs, the general overview giving some valuable pointers as to what variables are worth testing quantitatively. In addition, correlational research was used to measure two variables and asses the statistical relationship between them with little or no effort to control extraneous variables [4].

Likewise, the regression analysis was used to categorize the probable form of relationship among the variables. The method helped estimate the value of one variable corresponding to the value of another variable. From the method, the researcher was able to determine the contribution of the dependent variables either taken singly or in combination with the variation of performance in the teacher licensure examination.

\subsection{Participants of the Study}

The subjects of the research were first time LET takers. Both passers and non-passers participated in the study. A list issued by the Registrar's Office was the researcher's reference for the identification and addresses of the graduates. Actual participants were based on PRC issued lists of LET takers for the September 2009 to August 2014 examination schedule. Participants were identified and interviewed using Snowball sampling techniques. Snowball sampling is a non-probability sampling method where research participants encourage other participants to take part in the study. It is used when difficulty in finding potential participants is experienced [5]. At the end of data gathering, a total of 172 graduates from the school year 2009 to 2014 were identified. This consists of $86 \%$ of the Bachelor in Secondary Education and $82 \%$ of the Bachelor in Elementary Education graduates from 2009 to 2014 . A $100 \%$ retrieval of the questionnaire was not realized due to the inability to establish current addresses of the graduates and the time restriction for the completion of the study. Moreover, data on LET ratings were provided by the Professional Regulation Commission Manila, the Philippines through the researcher's request and endorsed by PRC Region 2, Tuguegarao City. 


\subsection{Research Instrument}

A researcher-constructed questionnaire in which the content was evaluated by the faculty of the teacher education department was administered. Revisions were made on the basis of the recommendations of the faculty-experts. The questionnaire elicited data on the profile and assessment of the curriculum and instructional variables. Copies of the questionnaire were distributed and retrieved through the Philippine Post (PhilPost) and private courier service providers. Graduates' GPA was obtained from the Registrar's Office upon the approval of the campus administrator.

\subsection{Statistical Treatment}

The graduates' GPA was converted into a percentage using the table of equivalents used by the University as stipulated in its Student Manual (2017). Mean was utilized to gauge the quality of the curriculum and the quality of the instruction provided by the college. The variables for the quality of the curriculum measured in terms of the degree of importance of each course in passing the LET were interpreted using the following scale: $1.0-1.8$, Not Important; 1.81 - 2.60, Least Important; $2.61-3.40$, Fairly Important; $3.41-4.20$, Important and $4.21-5.0$, Very Important. On the quality of instruction, the following scale was used: $1.0-1.8$, Never Practiced; 1.81 - 2.60, Seldom Practiced; 2.61 - 3.40, Sometimes Practiced; 3.41 - 4.20, Often Practiced and 4.21 - 5.0, Always Practiced. Correlation analysis through Pearson-r was conducted to test the association of the LET ratings with the mean GPA and mean rating of the quality of curriculum and quality of instruction whose results were interpreted based on Cohen 's interpretation [8] as shown in the following: $0.10-0.29$, weak; $0.3-0.49$, moderate; $0.50-1.0$, strong.

Finally, the regression analysis, through the Coefficient of Determination $\left(\mathrm{R}^{2}\right)$ was used to estimate how much variances in the licensure examination ratings are explained by the variables: academic performance, quality of curriculum and quality of instruction.

\section{Results and Discussions}

Among the 172 graduates who participated, $79.7 \%$ of them are single, and $76.7 \%$ are female, and the mean age is 24 . The mean GPA of the graduates is 88 , wherein using the university equivalence is tantamount to a "good" academic performance.

\subsection{Assessment of the Quality of Teacher Education Curriculum}

On the assessment of the importance of the different general education subjects in passing the Licensure Examination for Teachers, the table showed that graduates considered five (5) general education subjects to be very important in passing the LET, namely: English, Filipino, Natural Sciences, Mathematics, and Social Sciences. The remaining five subjects shown in Table 1, rated important by the graduates. The overall assessment by the graduates was that the General Education courses are important in passing the LET.

Table 1. Assessment of the Quality of the General Education Curriculum

\begin{tabular}{|c|c|c|c|c|c|c|c|c|c|c|c|c|}
\hline \multirow{2}{*}{$\begin{array}{c}\text { Subject } \\
\text { Clusters } \\
\text { English } \\
\text { Language }\end{array}$} & \multicolumn{2}{|c|}{$\begin{array}{l}\text { Attainment of } \\
\text { Subject } \\
\text { Objectives }\end{array}$} & \multicolumn{2}{|c|}{$\begin{array}{c}\text { Coverage of the } \\
\text { Contents of the } \\
\text { Subject }\end{array}$} & \multicolumn{2}{|c|}{$\begin{array}{c}\text { Quality of } \\
\text { Instructional } \\
\text { Materials Used }\end{array}$} & \multicolumn{2}{|c|}{$\begin{array}{c}\text { Teacher's Mastery } \\
\text { of the } \\
\text { Subject-matter }\end{array}$} & \multicolumn{2}{|c|}{$\begin{array}{l}\text { The relevance of } \\
\text { Subject } \\
\text { Assignments/Req } \\
\text { uirement }\end{array}$} & \multicolumn{2}{|c|}{$\begin{array}{c}\text { Overall } \\
\text { Assessment }\end{array}$} \\
\hline & 4.7 & VIm & 4.4 & VIm & 4.3 & VIm & 4.7 & Vim & 4.3 & Vim & 4.5 & Vim \\
\hline $\begin{array}{c}\text { Filipino } \\
\text { Language }\end{array}$ & 4.4 & VIm & 4.3 & VIm & 4.1 & $\operatorname{Im}$ & 4.6 & Vim & 4.1 & $\mathrm{Im}$ & 4.3 & Vim \\
\hline $\begin{array}{l}\text { Natural } \\
\text { Science }\end{array}$ & 4.4 & VIm & 4.3 & Vim & 4.2 & $\operatorname{Im}$ & 4.4 & Vim & 4.2 & $\operatorname{Im}$ & 4.3 & Vim \\
\hline Mathematics & 4.7 & VIm & 4.6 & VIm & 4.4 & VIm & 4.6 & Vim & 4.5 & Vim & 4.6 & Vim \\
\hline $\begin{array}{c}\text { Social } \\
\text { Science }\end{array}$ & 4.3 & VIm & 4.3 & VIm & 4.2 & $\mathrm{Im}$ & 4.5 & Vim & 4.3 & Vim & 4.3 & Vim \\
\hline $\begin{array}{l}\text { Mandated } \\
\text { Subjects }\end{array}$ & 3.9 & $\operatorname{Im}$ & 4.0 & $\operatorname{Im}$ & 3.7 & $\operatorname{Im}$ & 4.0 & Vim & 3.8 & $\operatorname{Im}$ & 3.9 & $\operatorname{Im}$ \\
\hline Humanities & 4.0 & $\mathrm{Im}$ & 3.9 & $\mathrm{Im}$ & 4.0 & $\mathrm{Im}$ & 4.2 & $\mathrm{Im}$ & 3.7 & $\mathrm{Im}$ & 4.0 & $\mathrm{Im}$ \\
\hline Computer & 3.9 & $\mathrm{Im}$ & 3.8 & $\mathrm{Im}$ & 3.8 & $\mathrm{Im}$ & 4.0 & $\mathrm{Im}$ & 3.7 & $\mathrm{Im}$ & 3.9 & $\mathrm{Im}$ \\
\hline $\begin{array}{c}\text { Physical } \\
\text { Education }\end{array}$ & 3.7 & $\mathrm{Im}$ & 3.7 & $\mathrm{Im}$ & 3.7 & $\mathrm{Im}$ & 3.9 & $\operatorname{Im}$ & 3.6 & $\mathrm{Im}$ & 3.7 & $\mathrm{Im}$ \\
\hline NSTP & 3.0 & FIm & 3.0 & FIm & 2.8 & FIm & 3.1 & FIm & 2.7 & FIm & 2.9 & FIm \\
\hline $\begin{array}{c}\text { General } \\
\text { Education }\end{array}$ & 4.1 & $\mathrm{Im}$ & 4.0 & $\mathrm{Im}$ & 3.9 & $\mathrm{Im}$ & 4.2 & $\mathrm{Im}$ & 3.9 & $\mathrm{Im}$ & 4.02 & $\mathrm{Im}$ \\
\hline
\end{tabular}

Legend: 1.0 - 1.8 (Not Important, NIm); 1.81 - 2.60 (Least Important, LIm); 2.61 - 3.40 (Fairly Important FIm); 3.41 - 4.20 (Important, Im); 4.21 - 5.0 (Very Important, Vim) 
In terms of the curriculum factors to which assessment was based, all the five (5) factors were considered important by the graduates. These assessment results suggest that the respondents after having experienced and having been exposed to the contents of the licensure examination, the graduates realized that the attainment of the course objectives of the different general education subjects, being able to discuss enough of the supposed topics to be covered within the semester, having used instructional materials that made the graduates able to internalized the most important concepts or principles supposedly learned in the course, mastery of the subject-matter by the faculty assigned to teach the subject and relevance of the instructional tasks and course requirements to the subject, all of these lead to the success in the licensure examination.

In terms of the professional education component, Table 2 reflects the results of the assessment of the graduates. The graduate-respondents assessed all the professional education subjects as very important in passing the LET. The results suggest that the graduates realized that each professional education subject would lead to success in the licensure examination. In terms of the factors to which assessment of the professional education subjects was based, the graduates rated four (4) factors as very important in passing the LET. Only the factor "coverage of the contents of the subject" was rated important.

Table 2. Assessment of the Professional Education Curriculum.

\begin{tabular}{|c|c|c|c|c|c|c|c|c|c|c|c|c|}
\hline Subject Clusters & $\begin{array}{l}\text { Attai } \\
\mathrm{Su} \\
\mathrm{Obj}\end{array}$ & $\begin{array}{l}\text { ent of } \\
\text { ect } \\
\text { ives }\end{array}$ & $\begin{array}{l}\text { Cov } \\
\text { the } \\
\text { of th }\end{array}$ & $\begin{array}{l}\text { ge of } \\
\text { itents } \\
\text { ubject }\end{array}$ & $\begin{array}{r}\text { Qua } \\
\text { Instr } \\
\text { Materi }\end{array}$ & $\begin{array}{l}\text { of } \\
\text { onal } \\
\text { Used }\end{array}$ & $\begin{array}{r}\text { Te } \\
\text { Mast } \\
\text { Subje }\end{array}$ & $\begin{array}{l}\text { ers } \\
\text { of the } \\
\text { Matter }\end{array}$ & $\begin{array}{l}\text { The rele } \\
\text { Assignm }\end{array}$ & $\begin{array}{l}\text { Subject } \\
\text { uirement }\end{array}$ & $\begin{array}{r}\mathrm{O} \\
\text { Ass }\end{array}$ & \\
\hline $\begin{array}{l}\text { Facilitating } \\
\text { Learning }\end{array}$ & 4.7 & VIm & 4.7 & Vim & 4.5 & VIm & 4.8 & VIm & 4.5 & VIm & 4.4 & Vim \\
\hline $\begin{array}{c}\text { Child and } \\
\text { Adolescent } \\
\text { Development }\end{array}$ & 4.8 & VIm & 4.7 & Vim & 4.5 & VIm & 4.7 & VIm & 4.5 & VIm & 4.5 & Vim \\
\hline $\begin{array}{l}\text { Social Dimensions } \\
\text { of Education }\end{array}$ & 4.6 & VIm & 4.5 & Vim & 4.5 & VIm & 4.7 & VIm & 4.3 & VIm & 4.4 & Vim \\
\hline $\begin{array}{c}\text { Principles of } \\
\text { Teaching I }\end{array}$ & 4.7 & VIm & 4.7 & Vim & 4.6 & VIm & 4.8 & VIm & 4.4 & VIm & 4.4 & Vim \\
\hline $\begin{array}{l}\text { Principles of } \\
\text { Teaching } 2\end{array}$ & 4.8 & VIm & 4.7 & Vim & 4.6 & VIm & 4.7 & VIm & 4.6 & VIm & 4.3 & Vim \\
\hline $\begin{array}{c}\text { Assessment of } \\
\text { Student Learning } 1\end{array}$ & 4.7 & VIm & 4.5 & Vim & 4.6 & VIm & 4.7 & VIm & 4.6 & VIm & 4.6 & Vim \\
\hline $\begin{array}{c}\text { Assessment of } \\
\text { Student Learning } 2\end{array}$ & 4.7 & VIm & 4.6 & Vim & 4.6 & VIm & 4.7 & VIm & 4.5 & VIm & 4.6 & Vim \\
\hline Ed. Tech. 1 & 4.6 & VIm & 4.4 & Vim & 4.4 & VIm & 4.6 & VIm & 4.4 & VIm & 4.5 & Vim \\
\hline Ed. Tech. 2 & 4.4 & VIm & 4.4 & Vim & 4.4 & VIm & 4.5 & VIm & 4.3 & VIm & 4.4 & Vim \\
\hline CurDev & 4.6 & VIm & 4.5 & Vim & 4.4 & VIm & 4.6 & VIm & 4.3 & VIm & 4.5 & Vim \\
\hline $\begin{array}{l}\text { Development } \\
\text { Reading }\end{array}$ & 4.6 & VIm & 4.4 & Vim & 4.4 & VIm & 4.6 & VIm & 4.3 & VIm & 4.5 & Vim \\
\hline $\begin{array}{l}\text { Teaching } \\
\text { Profession }\end{array}$ & 4.7 & VIm & 4.7 & Vim & 4.6 & VIm & 4.7 & VIm & 4.4 & VIm & 4.5 & Vim \\
\hline Field Study & 4.7 & VIm & 4.6 & Vim & 4.6 & VIm & 4.6 & VIm & 4.5 & VIm & 4.5 & Vim \\
\hline Practice Teaching & 4.7 & VIm & 4.7 & Vim & 4.6 & VIm & 4.6 & VIm & 4.5 & VIm & 4.5 & Vim \\
\hline $\begin{array}{l}\text { Professional } \\
\text { Education }\end{array}$ & 4.65 & VIm & 4.10 & $\operatorname{Im}$ & 4.52 & VIm & 4.66 & VIm & 4.4 & VIm & 4.47 & Vim \\
\hline
\end{tabular}

Legend: 1.0 - 1.8 (Not Important, NIm); 1.81 - 2.60 (Least Important, LIm); 2.61 - 3.40 (Fairly Important FIm); 3.41 - 4.20 (Important, Im); 4.21 - 5.0 (Very Important, Vim)

In terms of the curriculum factors to which assessment was based, all the five (5) factors were considered important by the graduates. These assessment results suggest that the respondents after having experienced and having been exposed to the contents of the licensure examination, the graduates realized that the attainment of the course objectives of the different general education subjects, being able to discuss enough of the supposed topics to be covered within the semester, having used instructional materials.

Of the 19 subjects under the specialization component of the BEEd curriculum, the graduates assessed 14 subjects which were very important in passing the LET. As reflected in Table 3, five were rated important. In terms of the five (5) factors to which the Specialization subjects were assessed, four factors, namely: attainment of the objectives of the subjects; coverage of the contents, teacher's mastery of the contents of the subject, and relevance of the projects required by the professors, were rated very important to satisfy in order for the subject to effectively prepare the graduates in the LET. 


\subsection{Assessment of the Quality of Instruction}

The graduates assessed the quality of instruction in the College of Teacher Education in terms of the processes and instructional procedures employed by the professors assigned to teach in the General Education, Professional Education, and major classes. Table 4 showed that the graduates rated the procedures and practices listed as "always" employed by the faculty of the Teacher Education Department. Eight (8) out of nine (9) procedures were consistently rated as "always employed" in their classes. Worthy to note was the reaction of the graduate-respondents on the item "classes coordinated by library work", the rating given by the graduates from all the three classes was "often," and this practice has the lowest rating. Hence, it is less employed in all the classes in the Teacher Education Department.

Table 3. Assessment of the Specialization Courses of the BEEd Program

\begin{tabular}{|c|c|c|c|c|c|c|c|c|c|c|c|c|}
\hline \multirow{2}{*}{$\begin{array}{l}\text { Content Courses } \\
\text { Children's Lit. }\end{array}$} & \multicolumn{2}{|c|}{$\begin{array}{l}\text { Attainment } \\
\text { of Subject } \\
\text { Objectives }\end{array}$} & \multicolumn{2}{|c|}{$\begin{array}{c}\text { Coverage of } \\
\text { the Contents } \\
\text { of the } \\
\text { Subject }\end{array}$} & \multicolumn{2}{|c|}{$\begin{array}{l}\text { Quality of } \\
\text { Instructional } \\
\text { Materials } \\
\text { Used } \\
\end{array}$} & \multicolumn{2}{|c|}{$\begin{array}{c}\text { Teacher's Mastery } \\
\text { of the Subject } \\
\text { Matter }\end{array}$} & \multicolumn{2}{|c|}{$\begin{array}{c}\text { The relevance of } \\
\text { Subject } \\
\text { Assignments/Requir } \\
\text { ement }\end{array}$} & \multicolumn{2}{|c|}{$\begin{array}{c}\text { Overall } \\
\text { Assessment }\end{array}$} \\
\hline & 4.3 & VIm & 4.23 & Vim & 4.12 & $\mathrm{Im}$ & 4.36 & Vim & 4.18 & $\mathrm{Im}$ & 4.25 & Vim \\
\hline Interactive English & 4.7 & VIm & 4.58 & VIm & 4.52 & Vim & 4.56 & Vim & 4.42 & VIm & 4.55 & Vim \\
\hline Campus Journalism & 4.1 & $\operatorname{Im}$ & 3.97 & $\operatorname{Im}$ & 3.86 & $\mathrm{Im}$ & 4.24 & Vim & 4.09 & $\mathrm{Im}$ & 4.04 & $\operatorname{Im}$ \\
\hline $\begin{array}{l}\text { Adv. Algebra \& } \\
\text { Trigonometry }\end{array}$ & 4.2 & VIm & 4.26 & Vim & 4.20 & $\operatorname{Im}$ & 4.44 & Vim & 4.38 & VIm & 4.30 & Vim \\
\hline Plane and Solid Geo. & 4.2 & VIm & 4.27 & Vim & 4.11 & $\operatorname{Im}$ & 4.36 & Vim & 4.32 & VIm & 4.26 & Vim \\
\hline $\begin{array}{l}\text { Analytic Geo.\& Intro to } \\
\text { Calculus }\end{array}$ & 4.3 & VIm & 4.20 & $\operatorname{Im}$ & 4.06 & $\mathrm{Im}$ & 4.45 & Vim & 4.44 & VIm & 4.30 & Vim \\
\hline $\begin{array}{c}\text { Seminar in Problem } \\
\text { Solving }\end{array}$ & 4.2 & Im & 4.17 & $\operatorname{Im}$ & 4.11 & $\operatorname{Im}$ & 4.36 & Vim & 4.33 & VIm & 4.23 & Vim \\
\hline Inorganic Chem. & 4.1 & Im & 4.14 & $\operatorname{Im}$ & 3.86 & $\operatorname{Im}$ & 4.38 & Vim & 4.12 & Im & 4.12 & $\operatorname{Im}$ \\
\hline $\begin{array}{l}\text { Physics for Health } \\
\text { Sciences }\end{array}$ & 4.3 & VIm & 4.41 & Vim & 4.23 & Vim & 4.44 & Vim & 4.44 & VIm & 4.36 & Vim \\
\hline Ecology & 4.4 & VIm & 4.33 & Vim & 4.29 & Vim & 4.50 & Vim & 4.27 & VIm & 4.35 & Vim \\
\hline Astronomy & 4.3 & VIm & 4.27 & Vim & 4.23 & Vim & 4.26 & Vim & 4.15 & Im & 4.24 & Vim \\
\hline Ang Panitikanng Pilipinas & 4.3 & VIm & 4.29 & Vim & 4.20 & $\operatorname{Im}$ & 4.41 & Vim & 4.23 & VIm & 4.28 & Vim \\
\hline $\begin{array}{c}\text { MgaAnyong } \\
\text { Kontemporaryong } \\
\text { Panitikan } \\
\end{array}$ & 4.4 & VIm & 4.26 & Vim & 4.11 & $\operatorname{Im}$ & 4.41 & Vim & 4.27 & VIm & 4.29 & Vim \\
\hline $\begin{array}{l}\text { Pagpapahayagng } \\
\text { Pampanitikan }\end{array}$ & 4.4 & VIm & 4.20 & $\operatorname{Im}$ & 4.35 & Vim & 4.44 & VIm & 4.14 & Im & 4.30 & Vim \\
\hline Foundations of MAPEH & 4.0 & Im & 4.05 & $\operatorname{Im}$ & 4.17 & $\operatorname{Im}$ & 4.42 & Vim & 4.18 & Im & 4.16 & $\operatorname{Im}$ \\
\hline Values Education & 4.3 & VIm & 4.38 & Vim & 4.18 & Im & 4.35 & Vim & 4.33 & VIm & 4.31 & Vim \\
\hline $\begin{array}{c}\text { Geography \& Natural } \\
\text { Science }\end{array}$ & 4.3 & VIm & 4.26 & Vim & 4.30 & Vim & 4.35 & Vim & 4.32 & VIm & 4.31 & Vim \\
\hline $\begin{array}{l}\text { Building Bridges Across } \\
\text { Discpl }\end{array}$ & 4.2 & $\operatorname{Im}$ & 4.20 & $\operatorname{Im}$ & 3.83 & $\operatorname{Im}$ & 4.32 & Vim & 4.45 & VIm & 4.20 & $\operatorname{Im}$ \\
\hline HELE & 4.2 & Im & 4.11 & $\operatorname{Im}$ & 4.11 & $\operatorname{Im}$ & 4.32 & Vim & 4.21 & VIm & 4.18 & $\operatorname{Im}$ \\
\hline Overall & 4.3 & Vim & 4.24 & Vim & 4.15 & $\operatorname{Im}$ & 4.39 & Vim & 4.28 & Vim & 4.27 & Vim \\
\hline
\end{tabular}

Legend: 1.0 - 1.8 (Not Important, NIm); 1.81 - 2.60 (Least Important, LIm); 2.61 - 3.40 (Fairly Important FIm); 3.41 - 4.20 (Important, Im); $4.21-5.0$ (Very Important, Vim)

\subsection{Assessment of the Quality of Instruction}

The graduates assessed the quality of instruction in the College of Teacher Education in terms of the processes and instructional procedures employed by the professors assigned to teach in the General Education, Professional Education, and major classes. Table 4 showed that the graduates rated the procedures and practices listed as "always" employed by the faculty of the Teacher Education Department. Eight (8) out of nine (9) procedures were consistently rated as "always employed" in their classes. Worthy to note was the reaction of the graduate-respondents on the item "classes coordinated by library work", the rating given by the graduates from all the three classes was "often," and this practice has the lowest rating. Hence, it is less employed in all the classes in the Teacher Education Department. 
Table 4. Assessment of the Quality of Instruction through the Instructional Procedures Employed by the Faculty

\begin{tabular}{|c|c|c|c|c|c|c|}
\hline \multicolumn{1}{|c|}{\begin{tabular}{c} 
Instructional Procedures \\
\hline
\end{tabular}} & Mean & Description & Mean & Description & Mean & Description \\
\hline $\begin{array}{c}\text { 1.a. Analytical and critical thinking is } \\
\text { promoted }\end{array}$ & 4.55 & Always & 4.68 & Always & 4.68 & Always \\
\hline $\begin{array}{c}\text { 1.b. Good attitude and appropriate } \\
\text { techniques in learning are encouraged }\end{array}$ & 4.41 & Always & 4.62 & Always & 4.76 & Always \\
\hline $\begin{array}{c}\text { Instructional processes used are: } \\
\text { 2.a. adapted to the subject matter }\end{array}$ & 4.48 & Always & 4.58 & Always & 4.55 & Always \\
\hline 2.b. adapted to students' capability & 4.38 & Always & 4.37 & Always & 4.50 & Always \\
\hline 2.c. adapted to situational needs & 4.40 & Always & 4.43 & Always & 4.40 & Always \\
\hline 2.d. suited to college-level instruction & 4.40 & Always & 4.52 & Always & 4.32 & Always \\
\hline 2.e. coordinated with library work & 3.95 & Often & 4.09 & Often & 4.20 & Often \\
\hline 2.f. conducive to an independent study & 4.20 & Often & 4.25 & Always & 4.29 & Always \\
\hline 2.g. related to actual life situations and \\
practice & 4.42 & Always & 4.58 & Always & 4.45 & Always \\
\hline
\end{tabular}

With the responses of the graduates in all items of the questionnaire consistent and almost all were "always" practiced, these results revealed that the quality of instruction in the Teacher Education department had reached a certain degree of quality. Graduates are all one in their reaction that instruction in the Department is geared towards the promotion of analytical and critical thinking, good attitude and technique in learning.

Table 5. Assessment of the Quality of Instruction through course Requirements

\begin{tabular}{|c|c|c|c|c|c|c|}
\hline Requirements & \multicolumn{2}{|c|}{ Gen Ed Classes } & \multicolumn{2}{c|}{ Prof Ed Classes } & \multicolumn{2}{c|}{ Major Subject classes } \\
\hline & Mean & Description & Mean & Description & Mean & Description \\
\hline Seatwork & 4.25 & Always & 4.28 & Always & 4.45 & Always \\
\hline Quizzes & 4.53 & Always & 4.53 & Always & 4.66 & Always \\
\hline Major Examinations & 4.78 & Always & 4.71 & Always & 4.77 & Always \\
\hline Recitation & 4.51 & Always & 4.54 & Always & 4.45 & Always \\
\hline Assignments & 4.03 & Often & 4.24 & Always & 4.25 & Always \\
\hline Oral Reports & 4.59 & Always & 4.66 & Always & 4.58 & Always \\
\hline Written Reports & 4.38 & Always & 4.51 & Always & 4.51 & Always \\
\hline Portfolio & 4.26 & Always & 4.53 & Always & 4.23 & Always \\
\hline Problem Sets & 4.21 & Always & 4.21 & Always & 4.40 & Always \\
\hline Performance Test & 4.41 & Always & 4.58 & Always & 4.37 & Always \\
\hline
\end{tabular}

In the teacher education curriculum, all the course requirements listed in Table 5 were rated by the graduates as "always" required by them except assignments in the Gen Ed classes with a mean of 4.03 and with a descriptive equivalent as "often" observed. This implies that it is necessary for future educators to accomplish tasks for them to be trained and be equipped in passing all the course requirements given by their professors.

Table 6 reveals the sources of written exercises given by the faculty of the College of Teacher Education. It was found out that the faculty of general education, professional education, and major courses always use self-prepared materials for their assessment tasks. For all faculty members, oftentimes written assessment materials are lifted from textbooks. Worthy to note is the observation that faculty of the general education courses limit their source of assessment materials to textbooks and self-made exercises. Items from LET review materials are only sometimes used as a reference for their assessment of students' learning. This result means that the faculty of general education courses rely less on commercially available sources of test items such as those found in LET or other professional examination reviewers. Rather, the faculty prefers to write their own assessment tasks which include written items or exercises. Since the faculty of the general education courses are Teacher Education graduates themselves, they may have applied the principles of test construction learned in their undergraduate professional courses. These include among others (1) good understanding of the subject matter on which test is to be made; (2) sufficient knowledge of the learners; and, (3) adequate knowledge of the medium of teaching and learning, which are understood by the teacher and learner. Danczak, S.M., et. al [9] in their review of 27 studies along the use of critical thinking tests concluded that assessment tasks 
designed by the teachers themselves are a better measure of critical thinking learning outcomes, as opposed to commercially available tools which attempt to measure critical thinking as a broad and generalized construct. Thus, this explains the result of this study.

Table 6. Sources of Written Exercises Administered by Instructors

\begin{tabular}{|c|c|c|c|c|c|c|}
\hline \multirow{2}{*}{ Source of Written Exercises } & \multicolumn{2}{|c|}{ Gen Ed Classes } & \multicolumn{2}{c|}{ Prof Ed Classes } & \multicolumn{2}{c|}{ Major Subject Classes } \\
\cline { 2 - 7 } & Mean & Description & Mean & Description & Mean & Description \\
\hline Textbooks & 3.67 & Often & 3.54 & Often & 3.49 & Often \\
\hline LET Review Materials & 3.22 & Sometimes & 3.63 & Often & 3.41 & Often \\
\hline Self-made exercises & 4.27 & Always & 4.27 & Always & 4.21 & Always \\
\hline Overall mean & 3.72 & Often & 3.81 & Often & 3.78 & Often \\
\hline
\end{tabular}

\subsection{Relationship Between the Variables}

The variable GPA generates an r-value of 0.502 , as reflected in Table 7 . This shows a strong and significant relationship to LET. Implying that a higher GPA is associated with a higher LET rating. This confirms the findings of Dagdag, J. et al. [10]; among the school-related factors, GPA was found having the strongest relationship with board examination performance. Thus, this confirms the higher the GPA, the greater would be the chance of passing the examination.

Table 7. Relationship between Variables and LET Performance

\begin{tabular}{|c|c|c|c|}
\hline Variables & r-value & Sig. & Remark \\
\hline GPA & 0.502 & 0.04 & Significant \\
\hline Attainment of Objective in Gen Ed subjects & 0.428 & 0.003 & Significant \\
\hline Content of the Gen Ed Curriculum & 0.180 & 0.018 & Significant \\
\hline Mastery of Subject matter of faculty in Gen Ed & 0.214 & 0.005 & Significant \\
\hline Attainment of Objective in Prof Ed & 0.168 & 0.028 & Significant \\
\hline The relevance of Requirements in the Prof Ed & 0.175 & 0.022 & Significant \\
\hline Sources of Written requirements in the Gen Ed subjects & 0.243 & 0.001 & Significant \\
\hline Sources of Written requirements in the Prof Ed subjects & 0.224 & 0.003 & Significant \\
\hline Sources of Written requirements in the Major subjects & 0.236 & 0.002 & Significant \\
\hline
\end{tabular}

The attainment of objectives in the General Education subjects was found having a moderate and significant relationship to LET general average rating. This denotes that quality education is achieved if objectives of the subject as specified in the course syllabi were attained. Consequently, the tendency to get high ratings in the LET.

In like manner, positive correlations exist on the coverage of the content of both general education subjects. This means that it is a necessity to finish the coverage of the course to attain a higher performance in the Board Examination. This explains that mastery learning of students who comprehend much and had learned much will likely to achieve a higher average LET rating.

In the same way, the relevance of assignments, mastery of the subject matter of the teacher, the attainment of objectives in the Professional Education and Gen Ed subjects and instructional quality is directly associated with LET performance. This reckons that better performance in the LET also depends on the relevance of assignments and the attainment of learning outcomes in the Professional Education subjects. Meaning, teaching the subjects in the General Education with relevant assignments, relevant requirements and the like helps LET takers gain a higher general rating in the board examination. Moreover, the teachers' mastery of the subject matter can help graduates in taking the Licensure examination for teachers. In addition, quality education is achieved through quality instructional materials. This also confirms the fact that learners grasp information faster and retain in their memory longer when discussed topics with concrete materials [11].

Every teacher should have criteria based on assessing students' performance. This variable reveals a highly significant correlation to the LET results. Thus, the high result of LET is evidence of proper assessment. This agrees to the idea of Visco [12] and Brillante [13] that the purpose of assessment is to improve learning and development.

The relevance of the requirements in the major subjects reveals a direct correlation to LET ratings of the graduates. 
More so, the sources of a written examination given by the instructors are highly significant to the LET average ratings of the graduates. This suggests that teacher-made written exercises, with established validity, make better instructional tools for both General Education and Professional Education subjects.

\section{Discussions}

\subsection{Assessment of the quality of the Curriculum and Instruction}

The assessment of the quality of the teacher education curriculum and the quality of instruction by the graduates is a way to determine the degree of correspondence of the different core subjects to the respective components of the LET. Having exposed to the contents of the LET, the graduates who took the licensure exam had a better view of the contribution of the different courses towards success in the LET. The realization that the attainment of the course objectives of the general education, professional and major components of the Teacher Education curriculum; being able to discuss enough of the supposed topics covered within the semester, having used instructional materials and assessment tools with established reliability and validity with LET measured competencies and relevance of the instructional tasks and course requirements to the teacher education courses, all of these lead to the success in the licensure examination. Thus, results confirm the theory that the quality of the curriculum is reflective of the quality of instruction provided among students [14]-[15]. Hence, learning outcomes must be observable, attainable, and assessable. It is a challenging task that requires continuous assessment and professional judgment from all program constituents. Consistent with these findings were the study of Dagdag, J., Dagdag, J., et al., and Adewale. A. et al.[16], [10], [17].

\subsection{The Contribution of Curriculum and Instructional Quality Variables to LET Performance}

Table 8. Regression Parameters of LET Performance

\begin{tabular}{|c|c|c|c|c|c|}
\hline & \multicolumn{2}{|c|}{$\begin{array}{c}\text { Unstandardized } \\
\text { Coefficients }\end{array}$} & \multicolumn{3}{c|}{ Standardized Coefficients } \\
\hline Model & B & Std Error & Beta & T & Sig \\
\hline Constant & 70.083 & 4.448 & & 15.756 & 0.000 \\
\hline MGEd & 0.524 & 0.137 & 0.420 & 3.816 & 0.000 \\
\hline CGEd & 0.472 & 0.160 & 0.326 & 2.959 & 0.004 \\
\hline
\end{tabular}

Adjusted $\mathrm{R}^{2}=0.026+0.069=0.095$ or $9.5 \% \mathrm{~F}$-ratio for regression $=$ $7.301 ; \mathrm{df}=171$ prob. $=0.001$

The Stepwise multiple regression analysis was used to determine the contribution of GPA, Curriculum and quality of instruction variables to the variance in the LET rating. As reflected in Table 8, from among the variables identified as significantly related to LET rating, teacher's mastery of the subject matter and course content of the General Education subjects, are the major contributors of the variances in the LET rating. As shown in the table, 9.5 percent of the variation in the LET rating of the graduates is attributed to the two predictors, mastery of the subject matter and content covered by the teachers of the general education classes. This means, for every unit increase in the mastery of the teacher (teaching Gen. Ed subject) there is a corresponding increase of .524 points in the LET rating of the graduate and for every unit increase of the content of the general education subjects discussed by the teacher, there is a corresponding increase of .472 points in the LET rating.

These findings confirm the results of the study conducted by Visco, D. [18] and Azurin[19], pointing to the quality of the general education curriculum as significant and strong predictors of the performance of graduates in the licensure examination.

The equation for the prediction model is as follows: Rating in the LET $=70.083+0.026$ (Gen Ed Teacher's mastery of the subject-matter) +0.069 (Coverage of the contents of the Gen Ed subject)

\section{Conclusions}

Passing the Licensure Examination for Teachers is a vital indicator of the success of the Teacher Education program. Prior knowledge, the expertise of the professors and quality services offered to students are hand in hand part of the success. Moreover, factors influential to the success in the Licensure Examination for Teachers are quality of the General Education curriculum and mastery of the subject matter among teachers of the General Education subjects. Hence, the performance in the Licensure Examination for Teachers will be at its best when the quality of the General Education curriculum is strengthened, and professors of general education subjects are educationally qualified to ensure mastery of the topics covered in the syllabi.

\section{REFERENCES}

[1] Baysal, Z. N. and Arac, K. E. (2019), Conditions determining quality in higher education: factors affecting satisfaction levels of prospective teachers., Universal Journal of Educational Research, July 01, 2019. DOI: 10.13189. Retrieved October 24, 2019, from www.hrpub.org

[2] "Philippine Teachers Professionalization Act of 1994" Republic Act 7836. Accessed on Nov 10, 2013. [Online]. Available: https://www.pcw.goc.ph.law.republic-act-7836

[3] "Commission on Higher Education Memorandum Order (CMO) No. 30. Series 2004. Accessed on Nov 10, 2013. [Online].Available: 
https://ched.gov.ph/memorandum-orders/

[4] M. Shuttleworth, How to choose between different research methods. Experiment Resources, 2008 Accessed on April 20, 2018 [online]. Available: http://www.experiment-resources.com/different-researchmethods.html

[5] www.sagepub.com/sites/default/files/upm-binaries/57732 Chapter_8.pdf, retrieved July 28, 2019.

[6] www.statisticshowto.datasciencecentral.com/snowball-sam pling/, Retrieved July 28, 2019

[7] Cagayan State University Student Manual, Revised 2017

[8] Cohen, J. (1988). Statistical Power Analysis for the Behavioral Sciences (2nd Edn). Hilldale, NJ: Lawrence Erlbaum Associates. 79-81.

[9] Danczak, S.M., Thompson, C.D. and Overton, T.L.(2019), Development and validation of an instrument to measure undergraduate chemistry students' critical thinking skills. Chemistry Education Research and Practice, July 12, 2019. DOI 101039. Retrieved July 28, 2019, from www.pubs.rsc.org

[10] Dagdag, J. S. (2017, November Part II). Examining the Factors of Licensure Examination for Teachers Performance for Program Strategy Enhancement. Asia Pacific Journal of Multidisciplinary Research, 5(4), 34-39. Retrieved March 22, 2019, from www.apjmr.com

[11] Brillante, S. T. (2014, April ). College of Computer Science. Retrieved from Ateneo De Naga University Web site: http://ccs.adnu.edu.ph

[12] Visco, D. (2015). Predictors of Performance in the licensure examination for teachers of the graduates of higher education institutions in Abra. International Journal of Management Research and Business Strategy, 4(1), 11-21. Retrieved February 2019

[13] Brillante, S. T. (2014, April ). College of Computer Science. Retrieved from Ateneo De Naga University Web site: http://ccs.adnu.edu.ph

[14] Tamayo, A. M. (2014, February 13). SSRN. DOI:10.2139/ssrn.2395037

[15] Mohammed, M. a. (2017, May). Licensure Examination Performance Evaluation of the Candidate Engineers as Basis for a Proposed Action Plan. Asia Pacific Journal of Multidisciplinary Research, 5(2), 51-57. Retrieved March 22, 2019, from www.apjmr.com

[16] Dagdag, J. D. (2018, May). Predictors of Performance in the Licensure Examination for Agriculturists: Bases for a Proposed Plan of Action. Asia Pacific Journal of Multidisciplinary Research, 6(2), 113-120. Retrieved March 22, 2019, from www.apjmr.com

[17] Adewale Adegunju, e. a. (2017, August). Cognitive and Psychosocial Predictors of Academic Achievement Among Pre-Service Teachers at the University of Ilorin, Nigeria. Asia Pacific Journal of Multidisciplinary Research, 5(3), 84-92. Retrieved March 22, 2019, from www.apjmr.com

[18] Visco, D. (2015). Predictors of Performance in the licensure examination for teachers Sof the graduates of higher education institutions in Abra. International Journal of Management Research and Business Strategy, 4(1), 11-21. Retrieved February 2019

[19] Azurin, H. C. (2008). Performance of Teacher Education Students in the Licensure Examination for Teachers. (Unpublished Dissertation). Aparri, Cagayan, Philippines: Cagayan State University. 